\title{
Peran Cahaya bagi Kehidupan Unggas: Respons Pertumbuhan dan Reproduksi
}

\author{
The Role of Light in Birds Life: The Response of Growth and Reproduction
}

\author{
Kasiyati \\ Departemen Biologi, Fakultas Sains dan Matematika, Universitas Diponegoro \\ Jl. Prof. Soedarto SH, Kampus UNDIP Tembalang Semarang \\ Email: atie_bd@yahoo.co.id
}

Diterima 8 Januari 2018 / Disetujui 22 Januari 2018

\begin{abstract}
ABSTRAK
Aves merupakan hewan model terbaik yang memberikan respons dengan adanya paparan cahaya artifisial. Pemanfaatan cahaya pada budi daya unggas telah lama diterapkan karena memiliki beragam keuntungan. Cahaya memiliki fungsi penting untuk mengatur ritme harian, pertumbuhan, hingga reproduksi, selain sebagai penerangan. Sistem perkandangan unggas modern menggunakan beragam sumber cahaya, salah satunya adalah light emitting diode (LED). Aspek pencahayaan yang diterapkan pada budi daya unggas dan masih terus diteliti hingga saat ini terdiri atas tiga hal penting, yaitu intensitas, warna, dan fotoperiode cahaya. Tujuan dari review artikel ini adalah mengkaji peran cahaya pada respons pertumbuhan dan performa reproduksi unggas. Penggunaan cahaya biru dan hijau meningkatkan pertumbuhan pada broiler dan puyuh, sedangkan pertumbuhan itik Pekin meningkat dengan adanya paparan cahaya biru dan merah. Cahaya merah maupun penggunaan cahaya dengan fotoperiode $16 \mathrm{~L}: 8 \mathrm{D}$ meningkatkan sintesis dan sekresi estradiol pada unggas lokal sehingga dalam jangka panjang dapat meningkatkan jumlah folikel ovari yang fungsional dan menjamin produksi telur berkelanjutan.
\end{abstract}

Kata kunci: cahaya monokromatik, unggas, pertumbuhan, estradiol

\begin{abstract}
Birds are the best model animal that response by exposure to artificial light. The utilization of light in poultry farming has long been applied because it has various advantages. Additionally, light has an important function to regulate circadian rhythm, growth, until reproduction. Modern poultry farming systems use a variety of light sources, one of which is the light emitting diode (LED). The lighting aspect applied to poultry farming and still being studied until now consists of three important things, i.e., intensity, color, and duration of light. The aim of this paper review is to update the role of light in the growth response and reproductive performance of poultry. The blue and green light could be used increased growth in broilers and quail, while the growth of Pekin ducks increased with the exposure of blue and red light. The red light and the used of light with $16 \mathrm{~L}$ : 8D photoperiod increased the synthesis and secretion of estradiol in local birds so in the long term it could be increased the number of functional ovarian follicles, and ensure continuous egg production.
\end{abstract}

Keywords: monochromatic light, poultry, growth, estradiol

\section{PENDAHULUAN}

Energi cahaya merupakan salah satu faktor lingkungan yang berperan penting dalam pengaturan bioritme hewan. Penggunaan cahaya artifisial pada hewan model menghasilkan respons yang sangat beragam, terutama pada metabolisme, reproduksi, dan tingkah laku. Berbagai hasil penelitian mengindikasikan, aves merupakan hewan model terbaik yang memberikan respons dengan adanya paparan cahaya artifisial. Pemberian cahaya artifisial tambahan pada malam hari, khususnya pada aves dapat menstimulasi perkembangan sistem reproduksi sehingga aves mencapai dewasa kelamin lebih awal (Kasiyati et al., 2011a), aves juga mengalami molting lebih dini dibandingkan kondisi malam yang gelap tanpa cahaya tambahan (Yang et al., 2016). 
Sistem pencahayaan yang dipergunakan pada budi daya unggas, terutama untuk menstimulasi pertumbuhan dan perkembangan sudah dikaji sejak tahun 1950 (Cao et al., 2012). Suplementasi cahaya juga sudah diterapkan pada industri perunggasan modern. Sistem perkandangan unggas modern telah menggunakan light emitting diode (LED) sebagai sumber cahaya karena memberikan keuntungan dalam efisiensi energi listrik, pancaran warna lebih stabil, lebih terang, awet (long life), serta dapat mengurangi kelembapan kandang. LED juga sering digunakan sebagai sumber cahaya monokromatik artifisial yang penerapannya dapat tunggal atau dikombinasikan di antara beberapa warna lampu.

Cahaya artifisial tidak hanya sebagai sumber penerangan pada budi daya unggas modern tetapi juga berperan pada respons reproduksi dan produksi unggas. Warna dan intensitas cahaya sangat esensial dalam modifikasi perilaku unggas, terutama ayam. Warna cahaya didefinisikan sebagai panjang gelombang cahaya. Cahaya dengan panjang gelombang berbeda dapat menstimulasi retina sehingga menghasilkan perubahan perilaku, pada tingkat selanjutnya berpengaruh pada pertumbuhan dan perkembangan unggas ( $\mathrm{Li}$ et al., 2014). Hasil penelitian sebelumnya yang telah dilaporkan memperlihatkan bahwa penggunaan cahaya monokromatik berpengaruh pada pertumbuhan dan perkembangan broiler berkaitan dengan umur, cahaya hijau menstimulasi pertumbuhan broiler pada usia muda, sedang cahaya biru menstimulasi pertumbuhan broiler pada usia yang lebih tua (Rozenboim et al., 1999). Baik cahaya hijau maupun biru lebih efektif dalam menstimulasi sekresi testosteron dan pertumbuhan miofibril sehingga menghasilkan peningkatan bobot tubuh (Cao et al., 2008). Penggunaan cahaya yang berkelanjutan dapat menghasilkan peningkatan bobot badan. Sebaliknya, paparan cahaya dalam waktu singkat dapat memperlambat pertumbuhan broiler (Ingram et al., 2000; Yang et al., 2015). Hassan et al. (2013) juga melaporkan cahaya dengan panjang gelombang panjang lebih mudah berpenetrasi pada jaringan kulit dan tulang tengkorak aves sehingga dapat menstimulasi kelenjar pituitari untuk mensekresikan hormon-hormon yang mengontrol reproduksi. Hormon tersebut diantaranya follicle stimulating hormone (FSH) dan luteinizing hormone (LH), serta estradiol (E2) yang disekresikan oleh folikel ovari terlibat langsung dalam pertumbuhan, perkembangan, dan menentukan jumlah folikel ovari. Kemungkinan terdapat berbagai mekanisme yang berkaitan dengan stimulasi cahaya pada respons pertumbuhan maupun reproduksi. Kajian mengenai aspek pencahayaan yang terlibat secara langsung dengan kesehatan, perilaku, dan fungsi fisiologis kehidupan unggas telah banyak dipublikasikan, namun ulasan mengenai hasil-hasil penelitian terkini yang berkaitan dengan peran cahaya bagi pertumbuhan dan reproduksi unggas masih sangat terbatas. Berdasarkan latar belakang yang telah disampaikan, tujuan dari review artikel ini adalah mengkaji informasi-informasi terkini mengenai peran cahaya pada respons pertumbuhan dan performa reproduksi unggas yang dapat menjamin produksi telur berkelanjutan.

\section{ASPEK PENCAHAYAAN}

Cahaya merupakan bagian dari fenomena alam yang kompleks, disebut sebagai radiasi elektromagnetik. Radiasi elektromagnetik dimulai dari sinar kosmik dengan panjang gelombang $10^{-18}$ $\mathrm{m}$, sinar gamma, sinar $\mathrm{X}$, dan sinar ultraviolet dengan panjang gelombang 4,0-7,8 x $10^{-7} \mathrm{~m}$, cahaya tampak dengan panjang gelombang 400$780 \mathrm{~nm}$, sinar inframerah, dan gelombang mikro memiliki panjang gelombang lebih dari $780 \mathrm{~nm}$, serta radar televisi dan radio yang dapat ditransmisikan hingga $6000 \mathrm{~km}$. Cahaya tampak merupakan porsi kecil dari total spektrum elektromagnetik, dengan panjang gelombang yang berbeda akan menghasilkan persepsi warna yang berbeda pula. Cahaya monokromatik merupakan jenis cahaya tampak dengan frekuensi panjang gelombang tunggal dan jarak antarpanjang gelombang tidak terlalu besar. Spektrum elektromagnetik cahaya monokromatik memiliki warna-warna tunggal berdasarkan panjang gelombangnya, yaitu merah $(630-760 \mathrm{~nm})$, jingga (590-630 nm), kuning (570-590 nm), hijau (500$570 \mathrm{~nm})$, biru $(450-500 \mathrm{~nm})$, dan ungu (400-450 nm) (Elert, 2008). 
Secara umum, cahaya yang berasal dari alam maupun cahaya buatan (artifisial) memiliki tiga aspek penting yang berbeda serta dapat mempengaruhi kehidupan unggas, yakni intensitas (iluminasi), panjang gelombang (warna cahaya), dan durasi pencahayaan (fotoperiode atau light schedule) (Andrew dan Zimmermann, 1990; Lewis dan Morris, 1998). Ketiga aspek cahaya tersebut terlibat secara langsung dalam tingkah laku, kenyamanan (welfare), kecepatan metabolisme, aktifitas harian, dan aktifitas fisiologis unggas, seperti pertumbuhan dan status reproduksi.

\section{Intensitas cahaya}

Intensitas cahaya merupakan fotometrik kuantitas cahaya yang jatuh pada permukaan suatu area. Pengukuran intensitas cahaya dalam kehidupan hewan merupakan hasil konversi dari pengukuran fotometrik intensitas cahaya yang diterima oleh manusia. Standar unit pengukurannya adalah lux, diperoleh dari kalibrasi cahaya tampak yang ekuivalen dengan $1 \mathrm{~lm} / \mathrm{m}^{2}$ (lumen per meter persegi) atau $0,08 \mathrm{~cd} / \mathrm{m}^{2}$ (candela per meter persegi) (Lewis dan Morris, 2006).

Perilaku unggas sangat dipengaruhi oleh intensitas cahaya. Hasil penelitian yang dilaporkan oleh Olanrewaju et al. (2006) menyebutkan bahwa cahaya terang lebih cepat meningkatkan aktivitas harian pada broiler, sedangkan cahaya dengan intensitas yang lebih rendah lebih efektif dalam mengontrol agresifitas atau mengurangi kanibalisme. Peningkatan intensitas cahaya yang diberikan dalam jangka waktu pendek pada sistem kandang unggas modern dapat meningkatkan pertumbuhan dan mengurangi abnormalitas tulang serta kelainan metabolisme. Hasil penelitian yang dilaporkan oleh Buyse et al. (1996) dan Li et al. (1995) menunjukan intensitas cahaya yang rendah (kurang dari 5 lux) menyebabkan degenerasi retina, glaucoma, miopi, dan kerusakan lensa yang mengarah pada kebutaan unggas komersial, terutama broiler. Berbeda dari hasil penelitian sebelumnya, Yahav et al. (2000) menemukan bahwa intensitas rendah (10 lux) meningkatkan konversi pakan pada kalkun sehingga menghasilkan peningkatan bobot badan.

\section{Durasi pencahayaan (lamanya pancaran cahaya)}

Durasi pencahayaan untuk cahaya natural menunjukkan periode (jangka waktu) pencahayaan yang berkaitan dengan panjang hari (daylength/photoperiod). Panjang hari dideskripsikan sebagai periode rotasi bumi selama 24 jam, yang terdiri atas periode tunggal dalam terang sebagai siang dan periode tunggal dalam gelap sebagai malam (scotoperiod) (Rodenboorg et al., 2001). Pengaruh utama yang muncul dari durasi pencahayaan adalah secara langsung terlibat dalam dewasa kelamin. Dewasa kelamin pada unggas betina berkaitan erat dengan pengeluaran telur, sedangkan pada unggas jantan dewasa kelamin ditandai dengan testis telah tumbuh dan berkembang serta mampu menghasilkan spermatozoa yang normal serta viabel (Lewis dan Morris, 2006). Anak broiler jantan yang dipelihara dengan fotoperiode konstan (23 jam terang: 1 jam gelap) dan fotoperiode intermittent berulang ( 1 jam terang: 3 jam gelap) menghasilkan kecepatan pertumbuhan yang lebih tinggi dengan konsentrasi hormon pertumbuhan serta testosteron plasma meningkat (Kuhn et al., 1996).

Durasi pencahayaan sebagian besar bergantung pada umur unggas dan tipe kandang yang dipergunakan. Broiler yang dipelihara pada periode gelap yang lebih lama memiliki status kesehatan lebih baik daripada periode terang lebih lama. Kondisi ini dapat diperjelas bahwa periode gelap menstimulasi sintesis dan sekresi melatonin. Melatonin dihasilkan oleh kelenjar pineal dan retina mata selama beberapa jam kondisi gelap sebagai respons aktivitas serotonin-Nasetiltransferase, enzim yang mengkatalisis pembentukan melatonin baik pada pineal maupun retina (Binkley et al., 1973). Melatonin yang berada dalam sistem sirkulasi berperan dalam pengaturan ritme sirkadian temperatur tubuh, fungsi metabolisme, pola konsumsi pakan/air minum dan digesti, serta sekresi beberapa limfokin yang berperan dalam fungsi normal sistem imun (Apeldoorn et al., 1999). Beberapa hasil penelitian yang telah dilaporkan kontradiksi dengan hasil penelitian sebelumnya, Moore dan Siopes (2000) melaporkan bahwa unggas yang dipelihara pada 
kondisi gelap mengalami sedikit gangguan kesehatan hingga peningkatan mortalitas dan kelainan tulang kaki (leg disorder). Unggas yang dipelihara dengan fotoperiode intermittent (berselang) lebih stress dibandingkan jika dikondisikan dengan fotoperiode kontinyu (konstan). Kondisi ini ditandai dengan meningkatnya kadar kortikosteron plasma (Olanrewaju et al., 2006). Selain itu, juga ditemukan rasio heterofil:limfosit yang lebih besar sebagai indikator stress (Siegel, 1995).

\section{Warna cahaya (panjang gelombang cahaya)}

Warna cahaya merupakan aspek cahaya yang sering dikenal dengan panjang gelombang dan memiliki berbagai macam pengaruh pada kehidupan unggas. Retina mata aves memiliki empat jenis fotoreseptor sel kerucut (cone), jumlahnya lebih sedikit, dan berfungsi untuk penglihatan normal pada siang hari (photopic), intensitas cahaya yang dapat diterima oleh sel kerucut adalah $4 \mathrm{~cd} / \mathrm{m}^{2}-44 \mathrm{~cd} / \mathrm{m}^{2}$ serta lebih banyak dipakai untuk membedakan warna (Lewis dan Morris, 2006). Keempat jenis sel kerucut masing-masing diselimuti oleh butiran minyak (oil droplet). Butiran minyak berperan sebagai filter dan penyerap cahaya dengan panjang gelombang tertentu sehingga cahaya dapat ditransmisikan serta melindungi mata dari efek sinar ultraviolet. Sensitivitas dari tiga jenis sel kerucut terutama untuk warna-warna dasar sehingga dikenal sebagai sel kerucut biru $(450 \mathrm{~nm})$, sel kerucut hijau (550 $\mathrm{nm})$, dan sel kerucut merah $(700 \mathrm{~nm})$. Jenis sel kerucut keempat merupakan sel kerucut yang membedakan dari mata manusia dan hanya dimiliki oleh aves, yaitu sel kerucut untuk mendeteksi sinar UV-A (320-400 nm). Puncak spektrum elektromagnetik mata aves serupa dengan mata manusia, yaitu 545-575 nm meskipun mata aves memiliki 4 jenis sel kerucut. Pemberian cahaya monokromatik artifisial pada ayam menunjukkan adanya sedikit perbedaan terhadap sensitivitas spektrum elektromagnetik pada panjang gelombang 400-480 $\mathrm{nm}$ dan 580-700 nm, yaitu mata ayam sangat responsif menerima cahaya pada kisaran panjang gelombang tersebut sehingga ayam mampu menerima cahaya artifisial yang lebih terang daripada manusia (Hart et al. 1999).

Cahaya pada siang hari memiliki distribusi panjang gelombang antara 400 hingga $700 \mathrm{~nm}$. Aves dapat menerima cahaya melalui jalur mata (retinal photoreceptor) maupun jalur sel-sel fotosensitif pada otak (extra-retinal photoreceptor). Berbagai hasil penelitian dengan pemberian warna cahaya pada unggas mampu memberikan respons yang berbeda (Gewehr et al., 2005). Cahaya biru yang diberikan pada ayam broiler jantan dapat menstimulasi produksi testosteron dan protein untuk menginduksi pertumbuhan sel-sel otot. Selain itu, cahaya biru menyebabkan unggas lebih tenang (Rozenboim et al., 2004). Secara alami, anak-anak unggas juga lebih menyukai kandang dengan cahaya biru (Davis et al., 1997). Cahaya hijau yang juga diberikan pada ayam broiler menstimulasi pertumbuhan sejumlah sel-sel otot dan tulang (Prayitno et al., 1997), sedangkan cahaya merah yang diterima oleh ayam broiler akan memacu hipotalamus untuk mensekresikan gonadotropin releasing hormone (GnRH). GnRH kemudian menstimulasi sekresi hormon-hormon reproduksi, seperti FSH, LH, estrogen, dan progesteron, yang pada akhirnya akan merangsang produksi telur. Sementara itu, cahaya merah yang diterima oleh itik jantan dapat meningkatkan respons fotoseksual, ditandai dengan bertambah besar ukuran testis yang diikuti oleh peningkatan bobot testis, sedangkan cahaya merah yang diterima oleh itik betina akan meningkatkan bobot dan ukuran telur (Lewis dan Morris, 2006).

\section{PERAN CAHAYA PADA PERTUMBUHAN UNGGAS}

Cahaya yang diterima oleh fotoreseptor, baik melalui jalur retina maupun ekstra-retina menjadi stimulan positif bagi hipotalamus. Hipotalamus akan mensekresikan faktor pelepas (releasing factor), seperti growth hormone releasing factor (GHRF) maupun tiroid realising factor (TRF). Releasing factor kemudian menstimulasi hipofisis anterior untuk mensintesis dan mensekresikan growth hormon $(\mathrm{GH})$ ataupun tiroid stimulating hormone (TSH). Hormon 
pertumbuhan $(\mathrm{GH})$ merangsang pertumbuhan selsel tulang dan otot, serta metabolisme lipid dan protein. Sementara itu, TSH menstimulasi kelenjar tiroid untuk mensekresikan hormon tiroksin. Hormon tiroksin dapat mempengaruhi berbagai enzim yang terlibat dalam metabolisme, meningkatkan aktivitas metabolisme, memacu penggunaan oksigen, dan meningkatkan persediaan energi. Hormon tiroksin juga berdampak pada peningkatan pertumbuhan. Berbagai informasi mengenai penelitian cahaya sebagai faktor lingkungan yang berpengaruh pada pertumbuhan unggas telah dilaporkan. Penulis menampilkan ringkasan dampak cahaya pada pertumbuhan unggas dari berbagai sumber (Tabel $1)$.

Tabel 1. Dampak penggunaan cahaya pada pertumbuhan unggas

\begin{tabular}{|c|c|c|c|c|}
\hline $\begin{array}{l}\text { Sumber } \\
\text { Cahaya }\end{array}$ & $\begin{array}{c}\text { Aspek } \\
\text { Pencahayaan }\end{array}$ & Jenis Unggas & Hasil Penelitian & Pustaka \\
\hline LED & Warna cahaya & $\begin{array}{c}\text { Anak broiler } \\
\text { jantan }\end{array}$ & $\begin{array}{l}\text { Cahaya hijau menstimulasi pertumbuhan pada } \\
\text { periode awal pertumbuhan, penggantian cahaya } \\
\text { artifisial dengan cahaya natural pada saat broiler } \\
\text { berumur } 10 \text { atau } 20 \text { hari memacu pertumbuhan } \\
\text { menjadi lebih cepat. }\end{array}$ & Rozenboim et al., 2004 \\
\hline LED & $\begin{array}{l}\text { Warna dan } \\
\text { intensitas cahaya }\end{array}$ & Broiler jantan & $\begin{array}{l}\text { Cahaya hijau meningkatkan pertumbuhan dan } \\
\text { performa produksi broiler pada tahap awal } \\
\text { pertumbuhan. Cahaya biru } 15 \text { lux meningkatkan } \\
\text { pertumbuhan pada tahap selajutnya. Baik cahaya } \\
\text { hijau maupun biru menstimulasi sekresi testosteron } \\
\text { sehingga meningkatkan pertumbuhan miofibril. } \\
\text { Pergantian cahaya hijau dengan cahaya biru dan } \\
\text { cahaya biru dengan cahaya hijau meningkatkan } \\
\text { pertumbuhan maupun performa produksi broiler. }\end{array}$ & Cao et al., 2008; 2012 \\
\hline LED & $\begin{array}{c}\text { Warna dan } \\
\text { intensitas cahaya }\end{array}$ & Puyuh & $\begin{array}{l}\text { Cahaya biru dan hijau, masing-masing dengan } \\
\text { intensitas } 25 \text { lux dapat meningkatkan bobot tubuh, } \\
\text { panjang tulang tibia, dan bobot muskuli pektoralis }\end{array}$ & Kasiyati et al., 2011b \\
\hline LED & Warna cahaya & Puyuh & $\begin{array}{l}\text { Performa pertumbuhan puyuh meningkat ditandai } \\
\text { dengan peningkatan bobot tubuh dan pertambahan } \\
\text { bobot tubuh pada cahaya hijau maupun kombinasi } \\
\text { antara cahaya merah dengan biru. Bobot muskuli } \\
\text { pektoralis dan bobot karkas paling tinggi terdapat } \\
\text { pada kombinasi antara cahaya hijau dengan biru. }\end{array}$ & $\begin{array}{l}\text { Kasiyati dan Muliani, } \\
2013\end{array}$ \\
\hline LED & Warna cahaya & Itik Pekin & $\begin{array}{l}\text { Performa pertumbuhan itik meningkat (bobot tubuh } \\
\text { dan pertambahan bobot tubuh) dengan paparan } \\
\text { cahaya merah dan biru. Rasio konversi pakan } \\
\text { meningkat pada cahaya hijau. Kualitas daging juga } \\
\text { meningkat pada cahaya hijau. }\end{array}$ & Kim et al., 2014 \\
\hline LED & Fotoperiode & $\begin{array}{l}\text { Anak broiler } \\
\text { betina }\end{array}$ & $\begin{array}{l}\text { Broiler yang dipelihara dengan } 22 \text { dan } 24 \text { jam } \\
\text { periode pencahayaan memiliki bobot badan lebih } \\
\text { berat dan pertambahan bobot badan meningkat } \\
\text { dibandingkan pada periode cahaya kurang dari } 20 \\
\text { jam. } \\
\text { Program pencahayaan kurang dari } 20 \text { jam juga } \\
\text { menurukan deposisi jaringan lemak abdominal. }\end{array}$ & Yang et al., 2015 \\
\hline$(-)$ & Fotoperiode & Anak itik Pekin & $\begin{array}{l}\text { Pertambahan bobot tubuh dan perkembangan karkas } \\
\text { meningkat pada fotoperiode } 24 \text { jam terang : } 0 \text { jam } \\
\text { gelap dibandingkan dengan fotoperiode } 16 \text { jam } \\
\text { terang : } 8 \text { jam gelap. }\end{array}$ & Erdem et al., 2015 \\
\hline LED & $\begin{array}{l}\text { Panjang } \\
\text { gelombang } \\
\text { (warna cahaya) }\end{array}$ & Broiler breeder & $\begin{array}{l}\text { Cahaya dengan panjang gelombang } \\
\text { merangsang pendek } \\
\text { sedangkan paparan cahaya dengan panjang } \\
\text { gelombang panjang meningkatkan produksi telur. }\end{array}$ & Yang et al., 2016 \\
\hline LED & $\begin{array}{c}\text { Warna dan } \\
\text { intensitas cahaya }\end{array}$ & Angsa breeder & $\begin{array}{l}\text { Cahaya putih, merah, dan biru tidak berpengaruh } \\
\text { pada pertumbuhan angsa. Peningkatan performa } \\
\text { reproduksi dan periode bertelur lebih lama terdapat } \\
\text { pada angsa yang terpapar cahaya merah dengan } \\
\text { intensitas } 30 \text { lux. }\end{array}$ & Chang et al., 2016a \\
\hline
\end{tabular}




\section{PERAN CAHAYA PADA REPRODUKSI UNGGAS}

Fungsi reproduksi unggas merupakan hasil kerja sama sistem neuroendokrin yang diregulasi oleh aksis hipotalamus, hipofisis, dan jaringan ovari itu sendiri. Hipotalamus memiliki tiga area yang berperan dalam fungsi normal reproduksi, yaitu kompleks nukleus infundibular yang mengandung sel-sel fotoreseptor hipotalamus, area preoptik berisi sel-sel yang memproduksi gonadotropin releasing hormone $(\mathrm{GnRH})$, dan area supraoptik sebagai tempat sekresi GnRHterinduksi progesteron. GnRH ditranspor ke dalam hipofisis anterior lewat sistem sirkulasi portal hipofisis yang menghubungkan antara hipotalamus dan kelenjar hipofisis. Kehadiran GnRH dalam hipofisis anterior akan menstimulusi pelepasan luitenizing hormone (LH) dan follicle stimulating hormone (FSH) (Etches, 2000). Cahaya merupakan salah satu faktor eksternal yang dapat menstimulasi hipotalamus untuk mensintesis dan mensekresikan GnRH (Gambar 1), baik melalui jalur retinohipotalamus maupun penetrasi langsung pada tulang kranial dan jaringan otak (Lewis dan Morris, 2006). Hipotalamus memiliki peran penting di dalam regulasi sekresi LH melalui umpan balik positif terkait dengan produksi progesteron dari folikel ovari yang berukuran paling besar (F1) pada folikel hierarki.

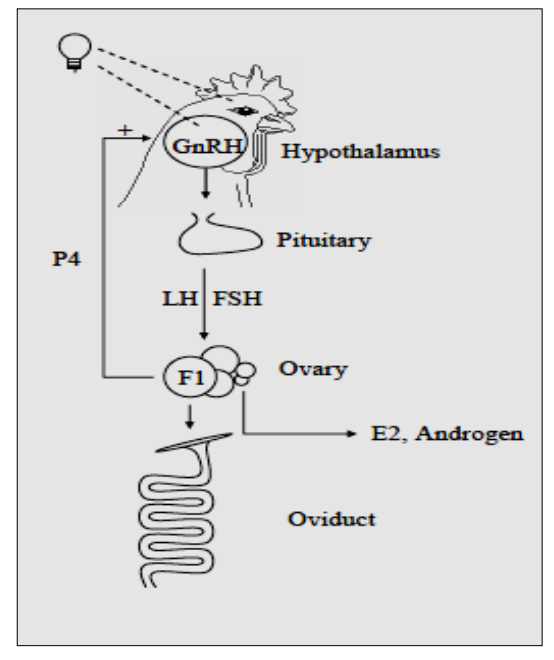

Gambar 1. Kontrol cahaya pada sistem reproduksi unggas betina. Ovulasi pada unggas merupakan hasil kerjasama antara hormon progesteron dan LH. GnRH: gonadotrophin releasing hormone; P4: progesterone; LH: luteinizing hormone; FSH: follicle stimulating hormone; E2: estradiol; F1: folikel matang terbesar pertama (folikel preovulasi) pada folikel hierarki (Alodan, 2001)

Sekresi FSH secara normal dapat dirangsang oleh periode pencahayaan (Etches, 2000; Squires, 2003; Lewis dan Morris, 2006). Perkembangan folikel akan menginisiasi sekresi estrogen pada sel-sel teka eksternal dan progesteron oleh sel-sel granulosa. Folikel prehierarki yang sedang tumbuh mensekresi estrogen dalam konsentrasi rendah. Seiring dengan perkembangan folikel prehierarki menjadi folikel hierarki, estrogen yang disekresi semakin meningkat. Estrogen memiliki pengaruh meningkatkan kadar kalsium, protein, lemak, vitamin, dan substansi lainnya dalam darah yang diperlukan untuk pembentukan telur. Pertambahan ukuran folikel pada folikel hierarki, terutama posisi $\mathrm{F} 1$ akan menurunkan sekresi estrogen dan meningkatkan sintesis progesteron. Progesteron disintesis oleh folikel preovulasi yang pada gilirannya dapat memacu hipofisis anterior untuk mensekresi LH. Jadi, progesteron yang disekresikan ke dalam darah merupakan umpan balik positif bagi sekresi LH dari hipofisis anterior. Kehadiran LH menyebabkan terjadinya ovulasi, yaitu pelepasan kuning telur (yolk) yang sudah matang dari ovarium ke dalam infundibulum. 
Masak kelamin pada unggas betina ditandai dengan proses ovulasi pertama kali (Etches, 2000; Squires, 2003). Berbagai penelitian mengenai aspek pencahayaan yang berpengaruh pada sifat- sifat reproduksi unggas sampai saat ini terus dikaji. Tabel 2 menyajikan ringkasan hasil penelitian penggunaan cahaya dan dampaknya pada reproduksi unggas.

Tabel 2. Dampak penggunaan cahaya pada reproduksi unggas

\begin{tabular}{|c|c|c|c|c|}
\hline $\begin{array}{l}\text { Sumber } \\
\text { Cahaya }\end{array}$ & $\begin{array}{c}\text { Aspek } \\
\text { Pencahayaan }\end{array}$ & Jenis Unggas & Hasil Penelitian & Pustaka \\
\hline LED & $\begin{array}{l}\text { Warna dan } \\
\text { intensitas } \\
\text { cahaya }\end{array}$ & Puyuh & $\begin{array}{l}\text { Cahaya biru } 15 \text { dan } 25 \text { lux meningkatkan } \\
\text { konsentrasi estradiol serum, diikuti dengan } \\
\text { peningkatan bobot ovari dan oviduk, serta diameter } \\
\text { folikel F1. }\end{array}$ & Kasiyati et al., 2010 \\
\hline LED & $\begin{array}{l}\text { Warna cahaya } \\
\text { dan fotoperiode }\end{array}$ & Ayam petelur & $\begin{array}{l}\text { Pemberian cahaya merah selama } 14 \text { jam yang } \\
\text { digantikan dengan cahaya hijau selama } 2 \text { jam } \\
\text { meningkatkan produksi FSH dan estradiol, bobot } \\
\text { ovari, jumlah folikel sehingga berdampak pada } \\
\text { produksi telur. }\end{array}$ & Hassan et al., 2013 \\
\hline LED & $\begin{array}{l}\text { Warna cahaya, } \\
\text { intensitas } \\
\text { cahaya, dan } \\
\text { fotoperiode } \\
\end{array}$ & $\begin{array}{c}\text { Ayam lokal } \\
\text { Sichuan China }\end{array}$ & $\begin{array}{l}\text { Cahaya biru dan merah masih dapat menstimulasi } \\
\text { reproduksi ayam petelur yang berumur } 440 \text { hari. } \\
\text { Cahaya hijau menurunkan produksi telur ayam } \\
\text { Sichuan. }\end{array}$ & Li et al., 2014 \\
\hline LED & Warna cahaya & $\begin{array}{l}\text { Ayam petelur } \\
\text { lokal Erlang } \\
\text { Mountain, } \\
\text { Sichuan China }\end{array}$ & $\begin{array}{l}\text { Cahaya biru dan hijau meningkatkan produksi telur, } \\
\text { ditandai dengan peningkatan sekresi estradiol dan } \\
\text { progesteron, juga diikuti dengan meningkatnya } \\
\text { ekspresi reseptor hormon-hormon tersebut. }\end{array}$ & Liu et al., 2015 \\
\hline$(-)$ & Warna cahaya & Merpati & $\begin{array}{l}\text { Cahaya merah meningkatkan jumlah telur. Ekspresi } \\
\text { gen BMAL1 pada aksis HPG (Hipotalamus- } \\
\text { Pituitari-Gonad) distimulasi oleh paparan cahaya } \\
\text { monokromatik. }\end{array}$ & Wang et al., 2015 \\
\hline LED & $\begin{array}{l}\text { Warna cahaya } \\
\text { dan fotoperiode }\end{array}$ & $\begin{array}{c}\text { Angsa Roman } \\
\text { jantan (Taiwan) }\end{array}$ & $\begin{array}{l}\text { Kadar testosteron maupun estradiol tidak berubah } \\
\text { dengan adanya cahaya monokromatik. } \\
\text { Rasio testosteron dengan estradiol pada angsa yang } \\
\text { terpapar cahaya puth lebih tinggi dibandingkan } \\
\text { dengan cahaya merah selama } 30 \text { minggu terpapar } \\
\text { cahaya. } \\
\text { Cahaya putih meningkatkan kualitas semen angsa } \\
\text { Roman. }\end{array}$ & Chang et al., 2016b \\
\hline LED & Warna cahaya & $\begin{array}{l}\text { Itik Magelang } \\
\text { (itik lokal } \\
\text { Indonesia) }\end{array}$ & $\begin{array}{l}\text { Cahaya merah meningkatkan sekresi estradiol yang } \\
\text { dipergunakan untuk menjamin keberlangsungan } \\
\text { vitelogenesis pada sel-sel hati itik magelang. }\end{array}$ & Kasiyati et al., 2016 \\
\hline LED & Fotoperiode & $\begin{array}{l}\text { Ayam petelur } \\
\text { Jing Hong China }\end{array}$ & $\begin{array}{l}\text { Ayam yang dipelihara dengan cahaya } 16 \text { jam terang } \\
: 8 \text { jam gelap dari umur } 19 \text { minggu mengalami } \\
\text { peningkatan jumlah small yellow follicle (SYF), } \\
\text { large white follicle (LWF), reseptor LH dan FSH. } \\
\text { Aktivitas SOD dan glutation peroksidase } \\
\text { mengalami penurunan pada plasma, hati, serta } \\
\text { ovari. }\end{array}$ & Chang et al., 2017 \\
\hline
\end{tabular}

\section{KESIMPULAN}

Unggas merespons cahaya dari lingkungan yang merupakan komponen penting pada pertumbuhan, perkembangan, dan reproduksi. Penggunaan cahaya biru dan hijau meningkatkan pertumbuhan pada broiler dan puyuh, sedangkan pertumbuhan itik Pekin meningkat dengan adanya paparan cahaya biru dan merah. Cahaya merah maupun penggunaan cahaya dengan fotoperiode
16 jam terang : 8 jam gelap (16 L : 8D) meningkatkan sintesis dan sekresi estradiol pada unggas lokal sehingga dalam jangka panjang dapat meningkatkan jumlah folikel ovari yang fungsional dan menjamin produksi telur berkelanjutan. 


\section{DAFTAR PUSTAKA}

Alodan, M.A., 2001. Cytokine IL-1 $\beta$ modulation of reproductive function in heat stressed hens. Dissertation. University of Nebraska. Lincoln Nebraska.

Andrew, D.K., N.G. Zimmermann. 1990. A comparison of energy efficient broiler house lighting sources and photoperiods. Poult. Sci. 69: 1471-1479.

Apeldoorn, E.J., J.W. Schrama, M.M. Mashaly, H.K. Parmentier. 1999. Effect of melatonin and lighting schedule on energy metabolism in broiler chickens. Poult. Sci. 78: 223-227.

Binkley, S., S.E. MacBride, D.C. Klien, C.L. Ralph. 1973. Pineal enzymes: Regulation of avian melatonin synthesis. Sci. J. 39: 333337.

Buyse, J., P.C.M. Simons, F.M.G. Boshouwers, E. Decuypere. 1996. Effect og intermittent lighting, light intensity and source on the performance and welfare of broilers. World's Poult. Sci. J. 52: 121-130.

Cao, J., Z. Liu, D. Wang, D. Xie, L. Jia, Y. Chen. 2008. Green and blue monochromatic light promote growth and development of broilers via stimulating testosterone secretion and myofiber growth. J. Appl. Poult. Res. 17: 211-218.

Cao, J., Z. Wang, Y. Dong, Z. Zhang, J. Li, F. Li, Y. Chen. 2012. Effect of combinations of monochromatic lights on growth and productive performance of broilers. Poult. Sci. 91: 3013-3018.

Chang, S.C., M. J. Lin, Z.X. Zhuang, S.Y. Huang, T.Y. Lin, Y.S. Jea, Y.K. Fan, T.T. Lee. 2006a. Effect of monochromatic lightemitting diode light with different color on the growth and reproductive performances of breeder geese. Asian Australas. J. Anim. Sci. 29 (6): 830-837.

Chang, S.C., Z.X. Zhuang, M.J. Lin, C.Y. Cheng, T.Y. Lin, Y.S. Jea. S.Y. Huang. 2016b. Effects of monochromatic light sources on sex hormone levels in serum and on semen quality of ganders. Anim. Repro. Sci. 167: 96-102.
Chang, Y., J. Feng, M. Zhang, L. Jiang, L. Zhai, X. Yang. 2017. Effects of massive ovulation on oxidation state and function of the ovaries in laying hens. Turk. J. Vet. Anim. Sci. 41: 161-166.

Davis, J., P.B. Thomas, T.D. Siopes. 1997. More evidence for light-dark growing. Broiler Industry. February: 31-32.

Elert, G., 2008. The nature of light. http://hypertexbook.com/physics/. Pebruari 2008).

Erdem, E., E.E. Onbasilar, O.G. Hacan. 2015. Effects of 16L:8D photoperiod on growth performance, carcas characteristics, meat composition, and blood parameters of Pekin ducks. Turk.J. Vet. Anim. Sci. 39: 568-575.

Etches, R.J., 1996. Reproduction in Poultry. CAB International, Singapore.

Gewehr, C.E., J.T. Cotta, A.I.G. Oliviera, H.J. de Freitas. 2005. Effect of lighting programs on the egg production of quails (Coturnix coturnix japonica). Agrotecno. 29(4): 139146.

Hart, N.S., J.C. Partrigde, I.C. Cuthill. 1999. Visual pigments, cone oil droplets, ocular media and predicted spectral sensitivity in the domestic turkey (Melleagris gallapavo). Vis. Res. 39(20): 3321-3328.

Hassan, Md.R., S. Sultana, H.S. Choe, K.S. Ryu. 2013. Effect of monochromatic and combined light colour on performance, blood parameters, ovarian morphology and reproductive hormones in laying hens. Ital. J. Anim. Sci. 12(e56): 359-364.

Ingram, D., L. Hattens, B. Mepherson. 2000. Effects of light restriction on broiler performance and specific body structure measurements. Physiol. Psychol. 9: 501504.

Kasiyati., N. Kusumorini, H. Maheshwari, W. Manalu. 2010. Fotostimulasi cahaya monokromatik untuk optimasi reproduksi dan karakteristik karkas puyuh (Coturnix coturnix japonica). Hal 118-122. Prosiding Peranan Teknologi Reproduksi Hewan 
dalam Rangka Swasembada Pangan Nasional. Bogor, 6-7 Oktober.

Kasiyati., N. Kusumorini, H. Maheshwari, W. Manalu. 2011a. Pemanfaatan cahaya monokromatik untuk memodulasi umur masak kelamin pada puyuh (Coturnix coturnix japonica). Berkala Ilmiah Biologi. 10: 9-15.

Kasiyati., A.B. Silalahi, I. Permatasari. 2011b. Optimasi pertumbuhan puyuh (Coturnix coturnix japonica) hasil pemeliharaan dengan cahaya monokromatik. Buletin Anatomi dan Fisiologi. 19(2): 56-65.

Kasiyati., H. Muliani. 2013. Peran kombinasi cahaya monokromatik dalam menstimulasi pertumbuhan matang kelamin puyuh (Coturnix coturnix japonica L.). Buletin Anatomi dan Fisiologi. 21(1): 64-74.

Kasiyati., Sumiati, D.R. Ekastuti, W. Manalu. 2016. Roles of curcumin and monochromatic light in optimizing liver function to support egg yolk biosynthesis in Magelang ducks. Inter. J. Poult. Sci. 15: 414-424.

Kim, M.J., R. Parvin, M.M.H. Musthaq, J.H. Kim, D.W. Kim, H. K. Kang, J.C. Na, J. Hwangbo, C.D. Kim, K.O. Cho, C.B. Yang, H.C. Cho. 2014. Influence of colored lightemittig diode illumination on the growth performance and meat quality traits of Pekin ducks (Anas platyrhynchos). Bulg. J. Agic. Sci. 20: 943-948.

Kuhn, E.R., V.M. Darras, C. Gysemans, E. Decuypere, L.R. Berghman, J. Buyse. 1996. The use of intermittentn lighting in broiler raising. 2. Effects on the somatotrophic and thyroid axes and on plasma testosterone levels. Poult. Sci. 75: 595-600.

Lewis, P.D., T.R. Morris. 1998. Responses of domestic poultry to various light sources. World's Poult, Sci. J. 54: 72-75.

Lewis, P., T. Morris. 2006. Poultry lighting the theory and practice. Northcot, Hampshire UK.

Li, T., D. Troilo, A. Glasser, H.C. Howland. 1995. Constant light procedurs severe corneal flatterning and hyperopia in chickens. Vision Res. 35: 1203-1209.

Li, D., L. Zhang, M. Yang, H. Yin, H. Xu, J.S. Trask, D.G. Smith, Z. Zhang, Q. Zhu. 2014. The effect of monochromatic light emitting diode light on reproductive traits of laying hens. J. Appl.Poult. Res. 23: 1-9.

Liu, L., D. Li, E.R. Gilbert, Q. Xiao, X. Zhao, Y. Wang, H. Yin, Q. Zhu. 2015. Effect of monochromatic light on expression of estrogen receptor (ER) and progesterone receptor $(\mathrm{PR})$ in ovarian follicles of chicken. Plos One. 10(12): 1-14. Doi: 10.1371.

Moore, C.B., T.D. Siopes. 2000. Effects of lighting conditions and melatonin supplementation on the cellular and humoral immune responses in Japanese quail Coturnix coturnix japonica. Gen. Comp. Endocrinol. 119: 95-104.

Olanrewaju, H.A., J.P. Thaxton, W.A. Dozier III, J. Purswell, W.B. Roush, S.L. Branton. 2006. A Review of lighting programs for broiler production. Inter. J. Poult. Sci. 5(4): 301-308.

Prayitno, D.S., C.J. Phillips, H. Omed. 1997. The effect color of lightting on behaviour and production of meat chickens. Poult. Sci. 76: 452-457.

Roodenboog, H., P. Noord, G. Oost, T. Slagharen. 2001. Sodium, green, blue, cool or warm white light. World's Poult. Sci. 17(12): 128134.

Rozenboim, I., I. Biran, Z.Uni, O. Halevy. 1999. The involvement of monochroamtic light in growth, development and endocrine parameters of broilers. Poult. Sci. 78: 135 138.

Rozenboim, I., I. Biran, Y. Chaiseha, S. Yahav, A. Rosenstrauch, D. Sklan, O. Halevy. 2004. The effect of greenand blue monochromatic light combination on broiler growth and development. Poult. Sci. 83: 842-845.

Siegel, H.S., 1995. Stress, strains and resistance. Br. Poult. Sci. 36: 3-22. 
Squires, E.J., 2003. Apllied Animal Endocrinology. CABI Publishing. Wallingford UK.

Wang, Y., J.T. Ding, H.M. Yang, Cao. W, Y.B. Li. 2015. The effect of new monochromatic light regimes on egg production and expression on the circadian gene BMAL1 in pigeons. Poult, Sci. 94: 836-840.

Yahav, S., S. Hurwitz, I. Rozenboim. 2000. The effect of light intensity on growth and development of turkey toms. Br. Poult. Sci. 41: 101-106.

Yang, Y.F., S.F. Jin, Z.T. Zhong, Y.H. Yu, B. Yang, J.M. Pan. 2015. Growth responses of broiler chickens to different periodss of artificial light. J. Anim, Sci. 93: 767-775

Yang, Y.F., J.S. Jiang, J.M. Pan, Y.B. Ying, X.S. Wang, M.L.Zhang, M.S. Lu, X.H. Chen. 2016. The relationship of spectral sensitivity with growth and reproductive response in avian breeders (Gallus gallus). Sci. Rep. 19. Doi: 10.1038/srep19291. 